\title{
Experts, experimenten en veepestbestrijding in de Oostenrijkse Nederlanden, 1769-1785
}

\author{
Filip Van Roosbroeck \\ TVGESCH 128 (1): 23-43 \\ DOI: 10.5117/TVGESCH2015.1.ROOS
}

\begin{abstract}
Experts, experiments, and the fight against rinderpest in the Austrian Netherlands, 1769-1785 When rinderpest broke out in the Austrian Netherlands in 1769, a policy of eradication was instituted in which koeimeesters - local lay veterinary healers - played a pivotal role. They continued to be relied upon despite criticism by academic doctors and the failure of experiments in which cures were attempted. This is explained by the construction of disease and expertise by both koeimeesters and doctors: since both groups saw disease as a matter of imbalance and corruption in the humours, necessitating an individual program of purgative and purifying remedies, neither was able to satisfy state demands for a quick and simple treatment. Nevertheless, the koeimeesters' ability to diagnose the illness, as well as their presence throughout the countryside, meant that government elites continued to rely on these lay healers and their judgement in the execution of policy.
\end{abstract}

Keywords: expertise, public health, epizootics, veterinary medicine, Enlightenment

Veeziekten zijn van alle tijden, maar in de achttiende eeuw werd de Europese runderstapel uitzonderlijk hard getroffen door drie grote golven van runderpest, in de jaren 1710 , 1740 en $1770 .{ }^{1}$ Runderpest is een veeziekte verwant aan de mazelen die een mortaliteitsgraad van maar liefst negentig procent kan bereiken; volgens C.A. Spinage stierven in de gehele achttiende eeuw in Europa zo'n tweehonderd miljoen runderen aan de ziekte. ${ }^{2}$ Tegen de runderpest werden in verschillende landen bestrijdingsmaatregelen genomen. In bijvoorbeeld de Nederlandse Republiek en de Duitse vorstendommen ging het om quarantainemaatregelen, het toedienen van remedies en het begraven van ge- 
storven dieren. ${ }^{3}$ In sommige gevallen werd echter de slacht van zieke dieren verplicht: dit was bijvoorbeeld het geval in Engeland en de Pauselijke Staten. ${ }^{4}$ In de Oostenrijkse Nederlanden was het overheidsingrijpen nog drastischer: hier omhelsde dit onder meer een invoerverbod, de verplichting dieren te laten keuren voor ze verplaatst mochten worden, en vooral het verplicht slachten en begraven van alle dieren die zich bevonden in een stal waarin de ziekte opdook. Ook werd er, toen bleek dat de landelijke bevolking zich aan deze bepalingen probeerde te onttrekken, al snel bepaald dat de provinciale overheden een schadevergoeding zouden betalen aan de eigenaars van het geslachte vee. ${ }^{5}$ Hoewel er in de

3 Zie voor de Republiek: J.A. Faber, 'Cattle-plague in the Netherlands during the eighteenth century', $M e$ dedelingen van de landbouwhogeschool te Wageningen, Nederland 62.11 (1962); P.A. Koolmees, 'Epizootic diseases in the Netherlands, 1713-2002', in: K. Brown en D. Gilfoyle ed., Healing the herds. Disease, livestock economies and the globalization of veterinary medicine (Athens OH 2010) 19-41; R. Rommes, "'Geen vrolyk geloei der melkzwaare koeijen”. Runderpest in Utrecht in de achttiende eeuw', Jaarboek Oud-Utrecht (2001) 87-135 en idem, 'Twee eeuwen runderpest in Nederland (1700-1900)', Argos 31 (2004) 33-40. Voor Duitsland: D. Hünniger, 'Policing epizootics. Legislation and administration during outbreaks of cattle plague in eighteenth-century northern Germany as continuous crisis management', in: Brown en Gilfoyle ed., Healing the herds, 76-91; R.A. Dorwart, 'Cattle disease (rinderpest?). Prevention and cure in Brandenburg, 1665-1732', Agricultural History 35 (1959); evenals de bijdragen in K. Engelken, D. Hünniger en S. Windelen ed., Beten, Impfen, Sammeln. Zur Viehseuchen- und Schädlings-bekämpfung in der Frühen Neuzeit (Göttingen 2007).

4 Enkel in 1745, toen de Britse regering werd afgeleid door een gelijktijdige opstand, kon de ziekte daar voet aan wal zetten, waarna ze nog dertien jaar aanwezig bleef: J. Broad, 'Cattle plague in eighteenth-century England', Agricultural History Review 31.2 (1983) 106.

5 F. Weymeers, Veeziekten en veeziektebestrijding 1770-1914. (KU Leuven, onuitgegeven licentiaatsverhandeling 1965) 19. literatuur wel enige aandacht is besteed aan deze programma's, is er opvallend weinig bekend over de uitvoering of de praktische invulling ervan. ${ }^{6}$ Wie stelde er bijvoorbeeld de diagnose? Wie bepaalde de te vergoeden waarde?

Het belang van deze vragen is eerder onderkend in onderzoek naar de veepest in Frankrijk. Toen in het zuidwesten van dat land in 1776 de veepest uitbrak, werd geprobeerd om hier eveneens de slacht van alle dieren te verplichten: 'The success of this operation depended', schrijft D. Brantz, 'on the joint effort of the medical establishment, the military, government officials and farmers. As it turned out, such cooperation was easier to demand than to implement'. ${ }^{7}$ Niet alleen waren er logistieke problemen, maar de gediplomeerden van de veeartsenijscholen van Lyon en Alfort waarop werd vertrouwd om de ziekte vast te stellen werden ook niet geaccepteerd door de lokale bevolking. Bovendien kwamen zij regelmatig in conflict met plaatselijke, ongediplomeerde maréchaux. $^{8}$ Dit soort strubbelingen bemoeilijkte een snelle bestrijding van de veepest: het was daarvoor van cruciaal belang dat de ziekte zo snel mogelijk, en met zo min mogelijk controverse, herkend en bestreden werd. Enkele recent verschenen studies benadrukken in navolging van de meer theoretische bijdragen

6 Zie bijvoorbeeld J Fischer, 'To kill or not to kill. The eradication of contagious bovine pleuro-pneumonia in western Europe', Medical History 47.3 (2003) 315. 7 D. Brantz. "'Risky Business". Disease, disaster and the unintended consequences of epizootics in eighteenth and nineteenth-century France and Germany', Environment and History 17 (2011) 40. Zie ook F. Vallat, 'An outbreak in France in the XVIIIth century. Rinderpest', Comptes Rendus Biologies 335 (2012) 347-348.

8 C. Hannaway, 'Veterinary medicine and rural health care in pre-Revolutionary France', Bulletin of the History of Medicine 51.3 (1977) 442-443. 
van Harry Collins het belang van de figuur van de expert als een belangrijke schakel tussen de staat (die gedurende de vroegmoderne periode meer taken naar zich toetrok) en lokale actoren met hun eigen belangen. De expert fungeerde hier als mediator, die door zijn specifieke vaardigheden problemen kon oplossen en communiceerde met alle betrokken partijen. ${ }^{9}$ Chandra Mukerji benadrukt hierbij het belang van 'epistemic credibility': het vertrouwen dat werd gehecht aan de kennis van de expert in kwestie. ${ }^{10}$

In de Oostenrijkse Nederlanden bestond het korps van 'experts' waarop een beroep gedaan werd voor het grootste deel uit 'koeimeesters': helers zonder academische scholing uit de plaatselijke gemeenschap, in sommige gevallen bijklussende smeden. Op hen werd gerekend om de correcte diagnose te stellen en de te slachten dieren een waarde toe te kennen. Maar waarom? Welke expertise bezaten zij, en waarom werden zij door de overheid vertrouwd? Over deze koeimeesters

9 Zie bijvoorbeeld de recente themanummers van Osiris 25.1 (2010) en Annals of Science 69.3 (2012). Eveneens interessant zijn de bijdragen in U. Klein en E.C. Spary ed., Materials and expertise in early modern Europe. Between market and laboratory (Chicago 2009); en de monografieën van Chandra Mukerji, Impossible engineering. Technology and territoriality on the Canal du Midi (Princeton 2009); en Eric Ash, Power, knowledge and expertise in Elizabethan England (Baltimore 2004). Zie ook Steven Shapin, Never pure. Historical studies of science as if it was produced by people with bodies, situated in time, space, culture, and society, and struggling for credibility and authority (Baltimore 2010); Harry Collins en Robert Evans, Rethinking expertise (Chicago 2007); en idem, 'The third wave of Science Studies. Studies of expertise and experience,' Social Studies of Science 32 (2002) 235-296. Een gedeeltelijk overzicht van deze literatuur is te vinden in $\mathrm{T}$. Broman, 'Working knowledge. Technical practices, social identities, and expertise in early modern Europe', Historical studies in the natural sciences 44.1 (2014). 10 Mukerji, Impossible engineering, 36. is nog weinig bekend. De oproep van de Engelse historicus Roy Porter om meer aandacht te besteden aan de geschiedenis van de geneeskunde from below ten spijt is vooral het achterhalen van de opvattingen van niet-academisch geschoolde genezers door het gebrek aan bronnen geen gemakkelijke opgave gebleken. ${ }^{11}$ De documenten over de veepestbestrijding vormen in dit opzicht echter een nagenoeg onontgonnen bron.

Vooral in de wat oudere literatuur wordt nogal eens laatdunkend gedaan over de 'pre-wetenschappelijke' veeartsenij, die louter zou bestaan uit 'volksmiddeltjes' of kwakzalverij, en over haar beoefenaars, die al snel worden afgedaan als ongeletterd en onkundig. ${ }^{12}$ Recentelijker heeft Louise Hill Curth echter betoogd dat er in het vroegmoderne Engeland wel degelijk een bloeiende literaire diergeneeskundige cultuur was, die nauw aansloot bij de galenische opvattingen van de menselijke geneeskunde. Zij kan echter

11 R. Porter, 'The patient's view. Doing medical history from below', Theory and Society 14.2 (1985) 175198. Zie over de moeilijkheid van het achterhalen van deze opvattingen bijvoorbeeld L. Brockliss en C. Jones, The medical world of early modern France (Oxford 1994) 274 en T. Wijsenbeek-Olthuis, 'Ziekte en tegenslag. Ziektebeleving in de hoogste kringen van de Republiek in de zeventiende eeuw', in: M. Gijswijk-Hofstra en F. Egmond ed., Of bidden helpt? Tegenslag en cultuur in Europa, circa 1500-200o (Amsterdam 1997) 73. Een zeldzame gedetailleerde studie van de opvattingen van een achttiende-eeuwse dokter en zijn patiënten is B. Duden, The woman beneath the skin (Cambridge 1991).

12 Zie bijvoorbeeld L. Wilkinson, 'Veterinary crosscurrents in the history of ideas on infectious disease', Journal of the Royal Society of Medicine 73 (1980) 821; J. Blancou, History of the surveillance and control of transmissible animal diseases (Parijs 2003) 176-177; J. Swabe, Animals, disease and human society. Humananimal relations and the rise of veterinary medicine (Londen 1999) 82; en R. Rommes, 'Geen vrolyck geloei', 126. 
niet veel zeggen over hoe deze opvattingen in de praktijk werden gebracht. ${ }^{13}$ François Vallat merkt op dat er in het achttiende-eeuwse Frankrijk nauwelijks verschil bestond tussen academische en populaire remedies tegen de veepest. Zijn bronnen laten dan weer niet toe om uitspraken te doen over achterliggende ideeën. $^{14}$

René De Herdt twijfelt in een studie over de Oostenrijkse Nederlanden aan de kunde van de koeimeesters en ziet zijn eigen twijfel gereflecteerd door de contemporaine overheid: deze zou na een reeks experimenten in 1769 haar vertrouwen in koeimeesters en remedies finaal zijn verloren. ${ }^{15}$ Nochtans bleven tot het verdwijnen van de veepest in 1785 de koeimeesters hun sleutelrol in de veepestbestrijding behouden - zij werden bijvoorbeeld niet vervangen door academisch geschoolde genezers, die in hun publicaties vrij veel kritiek hadden op de koeimeesters en eveneens experimenteerden met verschillende remedies.

De momenten waarop met remedies geëxperimenteerd mocht worden, bieden een ideale gelegenheid om de aard van de kennis van koeimeesters en artsen te onderzoeken, evenals hun relatie tot de overheid. In het eerste deel van dit artikel be-

13 L. Hill Curth, The care of brute beasts. A social and cultural study of veterinary medicine in early modern England (Leiden 2010).

14 F. Vallat, Les boeufs malades de la peste (Rennes 2009) 240-245. Ook de literatuur omtrent de menselijke geneeskunde benadrukt meer en meer het ontbreken van een echt onderscheid tussen 'geleerde' en 'volkse' geneeskunde. Zie voor een recent overzicht bijvoorbeeld M. Lindemann, Medicine and society in early modern Europe (Cambridge 2006).

15 R. De Herdt, Bijdrage tot de geschiedenis van de veeteelt in Vlaanderen, inzonderheid tot de geschiedenis van de rundveepest 1769-1785 (Leuven en Gent 1970) $5^{2-55}$. spreek ik daarom de twee testmomenten en hun context: in de abdij van Drongen in december 1769 en in het Brugse Vrije ruwweg een jaar later. Hieruit zal blijken dat deze experimenten niets veranderden aan het gebruik van de preventieve slacht, noch aan het inschakelen van koeimeesters in het uitvoeren van deze politiek. Om dit te verklaren komen in het tweede deel het ziektebegrip en de remedies van koeimeesters en artsen aan bod, evenals de manier waarop zij hun positie als expert legitimeerden. Ik zal duidelijk maken dat de doelstellingen van de overheid en de expertise van zowel koeimeesters als artsen uiteindelijk onverenigbaar waren: het probleem lag niet in de tegenstelling tussen verschillende vormen van geneeskunde, maar in de confrontatie tussen de framing van de ziekte door koeimeesters en artsen als een individuele aandoening die met een gepersonaliseerde aanpak moest worden behandeld, en de framing door de overheid als een besmetting die zo snel mogelijk in de kiem gesmoord moest worden. ${ }^{16}$ Nochtans werd de expertise van de koeimeesters wel aanvaard, en hun massale aanwezigheid op het platteland maakte dat zij snel bij elke uitbraak aanwezig konden zijn.

\section{Experimenten in Drongen}

Nadat in november 1769 de eerste gevallen van de runderpest werden vastgesteld in

16 Ik steun hier op het werk van Charles Rosenberg, die het belang benadrukt van het 'framen' van ziekte in onder andere het bepalen van publiek beleid: zie bijvoorbeeld C.E. Rosenberg, 'Disease in history. Frames and framers', The Milbank Quarterly 67.1 (1989) 115; of C.E. Rosenberg, 'The tyranny of diagnosis. Specific entities and individual experience', The Milbank Quarterly 80.2 (2002) 237-260. 
enkele dorpen rondom Gent, schrokken de gedeputeerden van de Staten van Vlaanderen aanvankelijk terug voor een strikte slachtpolitiek. ${ }^{17}$ Zelfs Vilain XIIII, voorzitter van de (gedeputeerden van de) Staten van Vlaanderen, voorschepen van Gent en uiteindelijk de voornaamste propagandist van de slachtpolitiek, was op dat moment nog optimistisch dat de ziekte bedwongen kon worden door simpelweg remedies toe te dienen. ${ }^{18}$ De raadsfiscaal van Vlaanderen, de vertegenwoordiger van de centrale regering die toezag op het naleven van de veepestordonnanties, waarschuwde er echter voor dat de ziekte zich verder zou kunnen verspreiden gedurende de periode dat geneesmiddelen werden toegediend. ${ }^{19}$

$\mathrm{Na}$ enkele dagen kwamen de gedeputeerden van de Staten van Vlaanderen, belast met het dagdagelijks bestuur van de provincie, tot de vaststelling dat de ziekte zich had verspreid via enkele ogenschijnlijk nog gezonde dieren die waren verkocht op de markt van Dendermonde. Om verdere verspreiding te voorkomen vroegen en kregen ze van de centrale overheid toestemming om verdere veemarkten voor een periode van drie tot vier weken te verbieden..$^{20}$ Een deputatie van het Brugse Vrije - een van de Vlaamse kasselrijen - die naar Gent kwam om hiertegen te protesteren, werd te woord gestaan door Vilain XIIII, die de maatregel verde-

17 Rijksarchief Gent [RAG], Staten van Vlaanderen $[S v V], 747$, brief van de gedeputeerden van de Staten van Vlaanderen (Gent, 16/11/1769).

18 RAG, $S v V$, 747, brief van Vilain XIIII (Gent, 18/11/ 1769). Zie over de voorschepen: Piet Lenders, Vilain XIII (Leuven 1995).

19 RAG, $S v V$, 747, brief van Dierickx (Sint-Niklaas, 19/ 11/1769).

20 RAG, $S v V$, 747, handschrift met hoofding 'Reflectien gemaeckt by de ghedeputeerde vande staeten van vlaenderen'. De toestemming kwam er 23/11. digde met het argument dat een ziek dier wel twaalf dagen besmettelijk kon zijn voordat er symptomen zichtbaar werden. $^{21}$

De gedeputeerden besloten de overgebleven getroffen dieren nu wel te slachten en te begraven. De idee dat dieren besmettelijk konden zijn voor het verschijnen van symptomen werd naar voren geschoven als doorslaggevend argument voor dit besluit. De argumentatie van de raadsfiscaal werd hierbij overgenomen: het toedienen van geneesmiddelen in de getroffen stallen kon verdere verspreiding van de ziekte niet voorkomen (in tegenstelling tot wat men eerder had gehoopt) en werd dan ook tot nader order uitgesteld: aangezien men de oorsprong van de besmetting had kunnen achterhalen, was het nu vooral zaak de bestaande ziektehaarden snel te dempen en verdere verspreiding te verhinderen door middel van het marktverbod. ${ }^{22}$

In december verspreidde de ziekte zich echter verder, binnen Gent zelf en naar Sint-Amandsberg; niet via contact tussen dieren onderling, maar door een onbekende oorzaak. ${ }^{23}$ Twee dagen later meldden afgevaardigden van de kasselrij Oudburg dat de plattelandsbevolking uit angst haar dieren te verliezen niet wilde meewerken aan de bestrijdingsmaatregelen.

21 Rijksarchief Brugge [RABR], Bundels Brugse Vrije $[B B V], 597$, rapport door burgemeester de Pelichy en pensionaris Onraedt (Brugge, 23/11/1769).

22 RABR, $B B V$, 597, verslag door Vilain XIIII (Gent, 24/11/1769). RABR, $B B V, 603$, brieven van Le Bailly de Marloop (Gent, 23/11/1769 en Gent 24/11/1769]; Algemeen Rijksarchief [ARA], Raad van Financiën $[R v F]$, 4445, brief van Van Overloope (Gent, 30/11/1769).

23 RABR, $B B V$, 597, brief van Le Bailly de Marloop (Gent, 04/12/1769). In het ene geval wordt verwezen naar een bewoner van een besmette boerderij die in een andere stal is commen vreyen eene dooghter synde de dienstmaerte'. 
Er werd besloten de kasselrij een som van drieduizend gulden toe te kennen om schadevergoedingen mee te betalen. ${ }^{24}$ Omdat de ziekte zich echter bleef uitbreiden, verzochten de gedeputeerden enkele dagen later aan de raadsfiscaal om 'lazaretstallen' te mogen oprichten waarin geneesmiddelen gebruikt zouden kunnen worden. De vraag om de verplichte slacht volledig af te schaffen, staat in de kladversie van hun brief maar is doorgestreept: de voortgaande verspreiding en de oplopende kosten maakten de gedeputeerden duidelijk nerveus. ${ }^{25}$ De toestemming kwam er en het verplicht slachten werd eveneens ingetoomd: dit bleef voortaan beperkt tot gevallen waar er 'imminent peryckel van communicatie' zou dreigen. ${ }^{26}$ De Gentse artsen Somers en Vander Woestijne, die eerder al enkele getroffen dieren hadden onderzocht, werden naar de abdij van Drongen gestuurd om daar geneesmiddelen uit te proberen.

Intussen werd in een nieuwe poging de ziekte een halt toe te roepen op 14 december besloten om alle runderen van Gentse brandewijnstokers - zo'n 125 dieren - op te kopen en te slachten. ${ }^{27}$ In Drongen waren de artsen aanvankelijk optimistisch, maar op 19 december moesten ze vaststellen dat de dieren die ze behandelden er plotseling veel slechter aan toe waren: een stalknecht had op eigen houtje een veel te

24 RAG, $S v V$, 748, verslag van een vergadering met de gedeputeerden (Gent, 06/12/1769).

25 RAG, $S v V$, 748, brief van de gedeputeerden (Gent, 09/12/1769). Dit blijkt ook uit een brief twee dagen eerder aan de voorzitter van de Raad van Vlaanderen, waarin ze klagen nog geen versoepeling van de slachtpolitiek te hebben verkregen: RAG, $S v V$, 748, brief van de gedeputeerden van de Staten (Gent, 07/12/1769). 26 RAG, $S v V, 748$, brief van raadsfiscaal Diericx (12/ 12/1769); RABR, BBV, 597, brief van de gedeputeerden. $27 \mathrm{RAG}, S v V, 748$, resolutie Staten van Vlaanderen (14/12/1769) zwaar middel toegediend, zeiden ze, waardoor de dieren niet meer te redden vielen. Enkele dagen later, op 22 december, rapporteerden ze geen enkele hoop meer te hebben op genezing. Tijdens de vergadering waarin dit rapport werd ontvangen stelde Vilain XIIII aan de verzamelde gedeputeerden voor de slachtpolitiek onmiddellijk te hervatten. ${ }^{28}$ In zijn schriftelijke voorstel werd alleen gerept van de negatieve uitkomst van de experimenten en niet van de verklaring van de artsen. Hij noemde de proefnemingen bovendien uiterst gevaarlijk omdat ze geleid hadden tot de verdere verspreiding van de ziekte, 'vermits de siekte agt dagen daer naer haer veropenbaert heeft in het gebuerte'. ${ }^{29}$

Op 28 december werd Vilains voorstel voorgelegd aan de vergadering van de Staten van Vlaanderen, samen met de ondertussen gepubliceerde bevindingen van Somers en Vander Woestijne en van de arts De Scheppere, die op verzoek van de raadsfiscaal zijn oordeel over de ziekte op papier had gezet en eveneens pleitte voor slachting. ${ }^{30}$ Tevens werd gevraagd om niet alleen het opnieuw verderzetten van de slachtpolitiek en het vergoeden van hierdoor getroffen eigenaars goed te keuren, maar eveneens om cordons te mogen instellen rond getroffen dorpen

28 RABR, $B B V$, 597, brief van Le Bailly de Marloop (Gent, 22/12/1769). Uiteindelijk werd dit werk gepubliceerd als Verhael ende reflexien op verbreydinge der besmettelyke siekte in het hoorn-vee de welke sig veropenbaert heeft in de Provintie van Vlaenderen t'sedert den 23. Octob tot den 23. Decemb. 1769 (Gent 1769) 29 Vilain XIIII, Verhael ende reflexien, 27-28. 30 J.B.B. De Scheppere, Oordeel over de nature mitsgaders de generale en particuliere oorsaeke der sieckte die onder het hoorn-vee binnen de Stadt Gendt en daer ontrent in de maendt November 1769. heeft beginnen te teeckenen (Gent 1769) 4; ARA, $R v F, 4445$, brief van raadsfiscaal Diericx (Gent, 24/12/1769). 


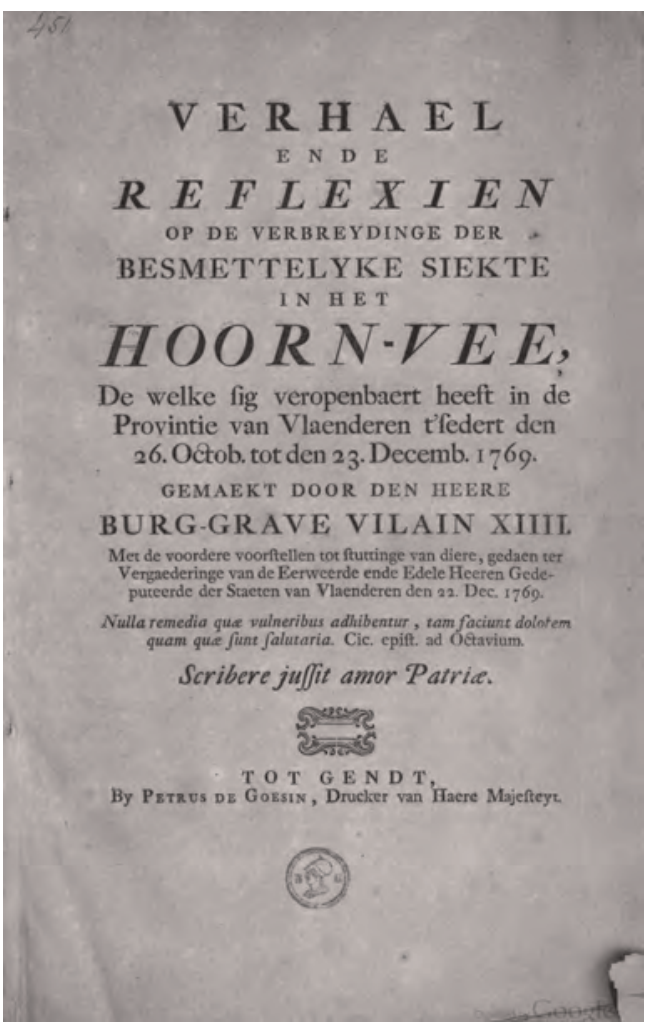

Titelblad van het pamflet van Vilain XIIII

waarbinnen alle runderen geslacht zouden worden. ${ }^{31}$ Aan het kasselrijbestuur van Dendermonde, dat zich niet kon vinden in dit voorstel, werd geantwoord dat het van vitaal belang was dat men de infectie de tijd niet gaf zich te verspreiden. ${ }^{32}$ Uiteindelijk werd dit voorstel goedgekeurd op 1 januari: de slachtpolitiek mocht worden voortgezet en de slachtingen zouden uit de provinciekas worden vergoed. ${ }^{33}$ Enkele dagen nadien werd een cordon rond Drongen, Gentbrugge en Oostakker getrokken en werden alle dieren in deze dorpen afgeslacht en vergoed, waarna de ziekte bedwongen leek.

31 RAG, $S v V, 748$, brief van de gedeputeerden (Gent, 28/12/1769).

32 RAG, $S v V$, 748, brief van kasselrijbestuur Dendermonde (Dendermonde, 31/12/1769).

33 RAG, $S v V$, 11178, drukwerk (Gent, o1/o1/1770)
Het had dus niet veel gescheeld of de slachtpolitiek zou in deze eerste maanden zijn verlaten: hoewel de gedeputeerden van de Staten al snel het idee aanvaardden dat besmetting kon plaatsvinden voordat er symptomen zichtbaar waren en dit hen deed overgaan tot een marktverbod en snelle slacht, werd de ziekte hier aanvankelijk niet door bedwongen. Omdat zij schadevergoedingen toekenden, liepen de kosten bovendien snel op. Pas nadat was gebleken dat de ziekte zich nog gemakkelijker verspreidde dan aanvankelijk was gedacht en de experimenten van de artsen Somers en Vander Woestijne als onbevredigend waren ervaren, werd volop ingezet op de slachtpolitiek. Ook toen de ziekte in de loop van 1770 terug opdook in verschillende kasselrijen werd daar voorlopig niet meer van afgeweken.

\section{Experimenten in het Brugse Vrije}

Pas nadat de ziekte in september 1770 was begonnen zich te verspreiden binnen Veurne-Ambacht en in oktober ook in het aangrenzende gebied van het Brugse Vrije (het zogenoemde Kamerlings Ambacht), werd tot andere acties besloten. Het kasselrijbestuur van Veurne had op 18 september al aan het Brugse Vrije laten weten dat de snelle en omvangrijke verspreiding van de ziekte in bepaalde gebieden 'd'executie van 's majesteyts placcaeten [...] onmogelyck is maeckende'. ${ }^{34}$ Wel werden besmette dorpen omringd door een cordon, waarbinnen gezonde dieren niet meer werden geslacht om excessieve verliezen (en excessieve schadevergoedin-

34 RABR, $B B V$, 599, brief van bestuur van VeurneAmbacht (Veurne, 18/o9/1770). 


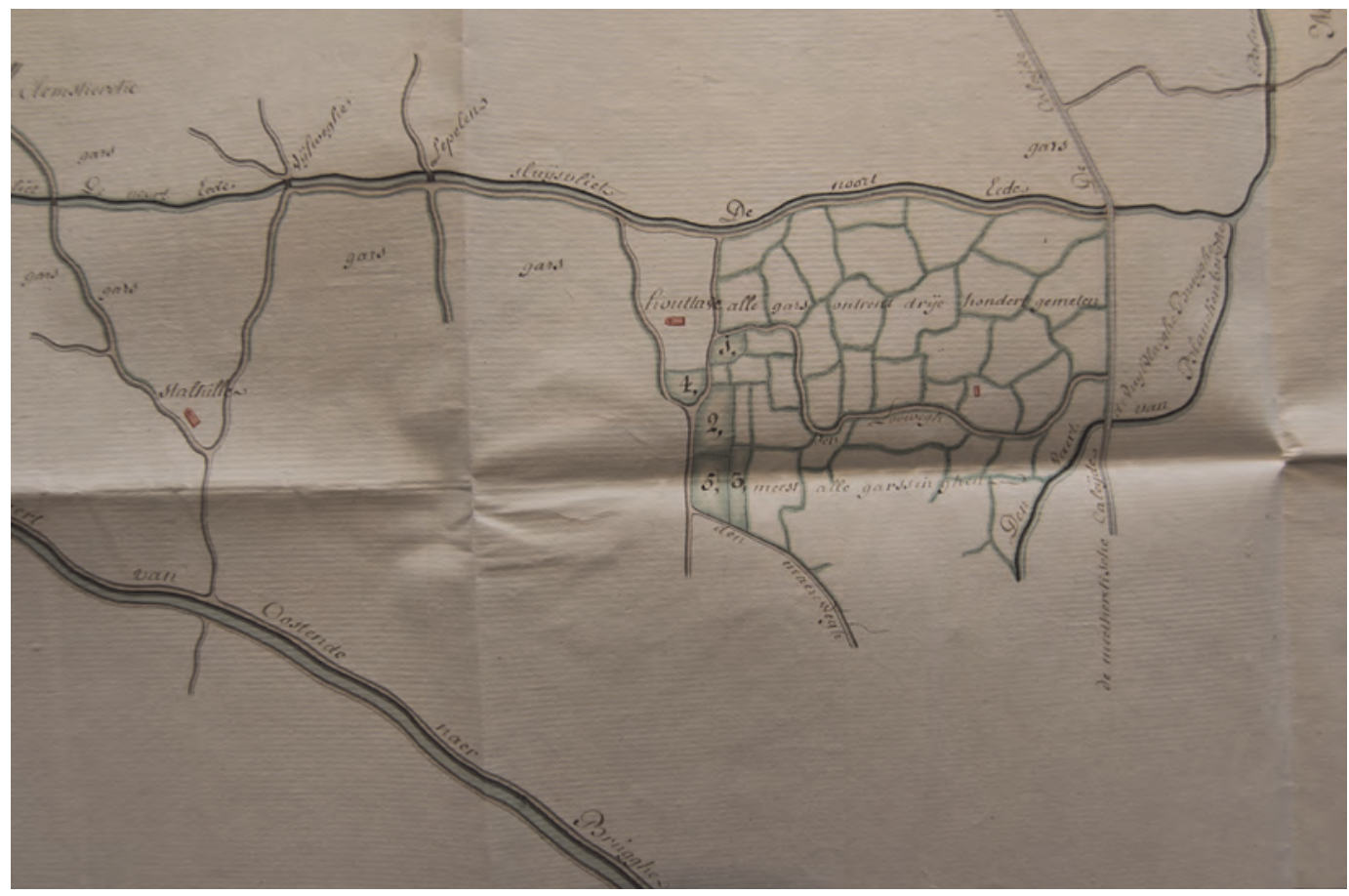

Kaartje van de polderstreek in het Brugse Vrije. Volgens het kasselrijbestuur van het Vrije van Brugge bemoeilijkte het landschap er de uitvoer van de slachtpolitiek

Algemeen Rijksarchief Brussel, Geheime Raad, 1247/A

gen) te vermijden. ${ }^{35}$ Dezelfde maatregel werd nadien eveneens toegepast in het Kamerlings Ambacht, hoewel de situatie er in november zo uitzichtloos leek dat werd voorgesteld de cordons rond individuele dorpen te verlaten en de troepen te gebruiken om het hele ambacht af te schermen van de rest van het Vrije. ${ }^{36}$

Hier werd echter over getreuzeld: de raadsfiscaal was ziek en zijn vervanger en de centrale overheid gaven tegenstrijdige signalen af. ${ }^{37}$ Op 28 november meldde het Vrije dat de ziekte zich uitgebreid had naar Klemskerke en Stalhille, dorpen die buiten het afgeschermde ge-

35 RABR, $B B V$, 599, brief van luitenant Joris (Poperinge, 09/10/1770)

36 RAG, $S v V$, 11178, brief van pensionaris Onraedt (Brugge, 04/11/1770)

37 RAG, $S v V, 749$, brief van pensionaris Onraedt (Gent, 12/11/1770) bied lagen, waarbij ze vreesden dat in geval van verdere uitbreiding 'van aldaer sekerlyck beth dan [meer dan] tweeduysent vette beesten misschien te sullen moeten doen dooden ende danof de weerde aen de eygenaers vergoeden, het gonne aen de provintie ten uyttersten lastelyck sal vallen'. ${ }^{38}$

De volgende dag al werd er vergaderd door de gedeputeerden van de Staten en vertegenwoordigers van de kasselrij Kortrijk, het Land van Aalst en het Brugse Vrije. Zij besloten de centrale overheid te vragen om alle gebieden waar de slacht niet meer werkte te mogen 'abandonneren', aangezien het zeker zou zijn dat de uitvoer van het edict daar zou leiden tot veel te grote kosten. Om deze gebieden af

38 RAG, $S v V$, 749, brief van het Brugse Vrije (Brugge, 28/11/1770) 
te zonderen van de nog gezonde stelden ze voor hier een cordon te trekken. Tevens vroegen ze om in de te verlaten gebieden, 'ten coste vande provintie sulkdanige remedien werckstellig te maecken, mitsgaders belooningen te belooven ende te doen, als sy geraedig sullen vinden'. ${ }^{39}$ Tot dit beleid werd uiteindelijk besloten op 15 december; ook zou getest worden of huiden, vet, roet, en schapen de ziekte konden overbrengen. ${ }^{40}$ Bovendien zouden er weer lazaretstallen worden opgericht om te trachten betrouwbare remedies te vinden: het lijkt daarbij vooral te zijn gegaan om remedies waarmee zelfs de 'eenvoudighen lantsman' overweg zou kunnen. ${ }^{41}$

Leden van het kasselrijbestuur werden naar de omgeving van Diksmuide gestuurd om enkele stallen te vinden waar experts hun remedies konden beproeven. Ook zouden ter controle enkele stallen worden geobserveerd waar geen actie zou worden ondernomen. De schepen die de leiding kreeg was bij voorbaat al sceptisch en meende dat 'gelyck meest alle de beesten in de sieckte verschillen, men geene sekere genees middelen en sal vinden'. ${ }^{42}$ In totaal zouden drie experts in enkele tientallen stallen pogingen ondernemen om dieren te genezen: na twee weken had koeimeester Joannes Terriere er van de 34 dieren zeven (of 21\%) genezen; een andere koeimeester, Hendrick Asset, had 14 van de 24 dieren ( $58 \%$ ) weten te genezen. ${ }^{43}$ De koeimeester Jan-Baptiste

39 RAG, $S v V$, 749, verslag vergadering (Gent, 29/11/ 1770).

40 RAG, $S v V$, 751, resolutie gedeputeerden (Gent, 15/ 12/1770).

41 RAG, SvV, 751, brief van pensionaris Onraedt (Brugge, 18/12/1770).

42 RABR, $B B V$, 598, brief van commissaris Mergaert (Vlasloo, 30/12/1770).

43 RAG, $S v V$, 752, brief van commissaris Maryssael (Leffinge, 03/01/1771).
Hoornaert tot slot had 56 van de 98 dieren (57\%) genezen. ${ }^{44}$ Alle niet genezen dieren waren gestorven. Van de zestig niet-behandelde dieren waren er $3^{2}$ genezen $(53 \%)$ en 28 gestorven. ${ }^{45}$ Deze proefnemingen lijken door het ambacht Assenede alvast als succesvol te werden beschouwd: op 8 maart vroegen ze het verplicht slachten van gezonde dieren af te schaffen, aangezien bewezen was dat de toepassing van 'conveniente remedien' veel meer dieren had geconserveerd dan de ziekte had weggerukt. Het antwoord van Vilain XIIII was kort en bondig: de gedeputeerden konden hier niet mee instemmen, te meer omdat door de lange duur van het genezingsproces de ziekte zich toch zou kunnen verderzetten. ${ }^{46}$ Ook de centrale overheid was hiervan overtuigd en verspreidde een anoniem pamfletje waarin de proefneming in het Brugse Vrije onomwonden als mislukt werd beschreven: de resultaten van de drie koeimeesters werden opgeteld en op basis hiervan werd geconcludeerd dat hun behandelingen niet tot betere resultaten hadden geleid dan niets doen. ${ }^{47}$ Bovendien werd gesteld dat het toedienen van geneesmiddelen sowieso een langdurig, moeilijk en duur proces was; het oncontroleerbaar verspreiden van de ziekte in het Brugse Vrije en Veurne-Ambacht had volgens de centrale overheid enkel verme-

44 RAG, $S v V, 75^{2}$, brief van commissaris Mergaert (Beerst, 18/01/1771).

45 RAG, $S v V, 75^{2}$, brief van commissaris Van Vossen (Essen, 14/01/1771)

46 RAG, $S v V$, 753, brief van het ambacht Assenede (Assenede, 08/03/1771).

47 RAG, $S v V, 753$, brief van gouverneur Charles-Alexander (Brussel, 05/03/1771); Verhael van den oorsprong ende voortgank der behaelyke siekte onder het hoorn-vee in de Oostenryksche provintien der Nederlanden (Gent 1771) 35-36. 
den kunnen worden door een nauwgezettere toepassing van de slachtpolitiek. ${ }^{48}$

De gelijktijdige experimenten waren niet succesvol in de zin dat het niet duidelijk was of de ziekte was overgedragen via huiden, roet of schapen of door een fout in de procedure. Niettemin werd besloten om nieuwe proeven uit te voeren, maar deze beslissing werd niet uitgevoerd. ${ }^{49}$ Tijdens de lentemaanden van 1771 leek de ziekte namelijk weer compleet te verdwijnen. Deze ontwikkeling werd toegeschreven aan de ruiming van de laatste besmettingshaarden. Toen de ziekte in de zomer toch weer opdook in het Brugse Vrije, ditmaal in het noorden, beschuldigde de centrale overheid het kasselrijbestuur van onwil en incompetentie. ${ }^{50}$ Van het testen van remedies was dit keer geen sprake meer. Het opnieuw wegebben van de ziekte in de lente van 1772 werd gezien als het resultaat van de oprichting van een comité in Gent dat speciaal belast was met de bestrijding van de veepest en een striktere naleving van de slachtpolitiek. ${ }^{51}$ Ook in de jaren die volgden, waarde de veepest nog rond in de Oostenrijkse Nederlanden, maar dit leidde nooit meer tot een oncontroleerbare uitbraak zoals tussen 1770 en 1772 . De slachtpolitiek werd

48 Verhael van den oorsprong, 28.

49 RAG, $S v V$, 753, brief van de gedeputeerden (Gent, 21/02/1771)

50 Dit komt nog het duidelijkst tot uiting in een verslag van afgevaardigden van het Brugse Vrije, die zowel door von Starhemberg als door de raadslieden Plubeau van de Geheime Raad en Paradis van de Raad van Financiën 'hebben moeten ontfangen reprochen benevens een doorsnydende mercuriael over de soogeseyde negligentie in het doen executeren der placcaeten'. RABR, $B B V, 601$, verslag (Brugge, 05/10/ 1771).

$5^{1}$ RABR, $B B V, 604$, brief van de jointe voor Vlaanderen (Gent, 07/02/1772); RAG, $S v V$, 11183, brief van Geheime Raad (Brussel, 16/03/1772) niet meer ter discussie gesteld; voor verdere uitgebreide proefnemingen waren de gedeputeerden van de Staten van Vlaanderen niet meer te vinden. Op het voorstel van een zekere dr. Van Eerlande om te experimenteren met inoculaties werd bijvoorbeeld niet ingegaan. ${ }^{52}$

De experimenten in het Vrije vonden dus plaats op een moment dat de slachtpolitiek gefaald leek te hebben. Op deze situatie werd gereageerd door enkele koeimeesters remedies te laten testen. De centrale overheid en de gedeputeerden van de Staten ervoeren deze experimenten als onbevredigend - de positieve evaluatie van bijvoorbeeld het bestuur van het ambacht Assenede ten spijt. Hoewel ook de proefnemers optimistisch waren, werd afgezien van verdere proeven. Net als bij de experimenten van Somers en Vander Woestijne lijkt het fundamentele probleem dat de voorgestelde remedies verdere verspreiding niet zouden kunnen vermijden, ongeacht hun effectiviteit of potentieel. Om dit te kunnen begrijpen, moeten we de opvattingen over ziekte en genezing van de verschillende actoren nader onder de loep nemen.

\section{Een gevoel voor humoren}

Wat gebeurde er in het lichaam van het zieke rund? In deze paragraaf beschrijf ik hoe verschillende groepen deze vraag beantwoordden en welke remedies zij voorstonden. De opvattingen van de medische en bestuurlijke elite zijn bewaard geble-

52 RAG, Raad van Vlaanderen [RAV], 32006, brief van Van Eerlande (Wervik, 21/10/1773). Dit in tegenstelling tot bijvoorbeeld Engeland en de Republiek: C. Huygelen, 'The immunization of cattle against rinderpest in eighteenth-century Europe', Medical History 41.2 (1997) 182-196. 


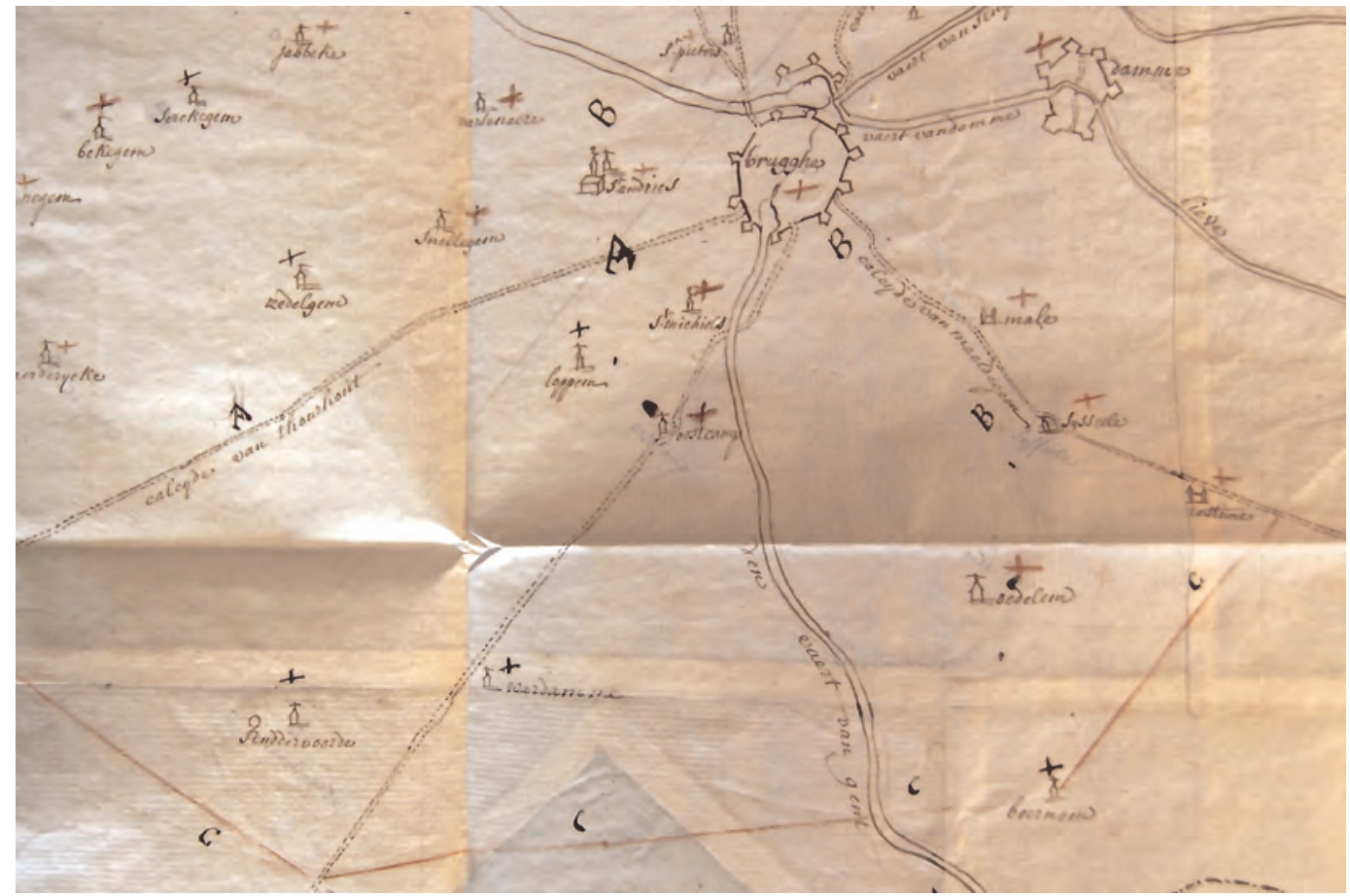

Om de verspreiding van de ziekte tegen te gaan, werden er op verschillende momenten cordons getrokken (op dit kaartje aangeduid met de letters ' $\mathrm{A}$ ', 'B' en 'C')

(C) Algemeen Rijksarchief, Secretarie van State en Oorlog, 2142

ven in talrijke publicaties en manuscripten en daarmee relatief gemakkelijk te achterhalen. Volgens Vilain XIIII bijvoorbeeld werd de ziekte veroorzaakt door een 'besmettelijk venijn' dat enige tijd nodig had om zich 'uit te broeden'. Pas nadat het lichaam vergeven was van deze stof wierp het gif 'sig seffens op eenig edel deel binnen de Beeste, welk deel besmet zynde, beginnen allengskens de teekenen hun uytwendig te openbaeren'. De eerste algemene aftakeling was niet van buitenaf merkbaar, maar wanneer er een autopsie

53 Vilain XIII, Verhael ende reflexien 23. Zoals eerder al vermeld, werd dit boek door de provinciale en centrale overheid uitdrukkelijk naar voren geschoven als dé verdediging van de afslachtpolitiek en zodoende op honderden exemplaren verspreid. Zie bijvoorbeeld RAG, $S v V, 11176$, brief van Vanden Cruyce (Hoogstraten, 04/01/1770); RAG, SvV, 748, brief van de gedeputeerden (Gent, 28/12/1769). werd uitgevoerd op dieren die in deze eerste fase stierven, 'vont men de selve van binnen met de gangrene, zulken afgrysselyken stank van hun gevende, dat de experte geene voordere ondersoeken bestonden te doen'. ${ }^{53}$

Vilain XIIII had dus geen modern ziektebegrip in de zin dat hij bepaalde symptomen verklaarde door pathologische veranderingen binnen het ene of het andere orgaan. Aantasting van organen vond in zijn ogen pas plaats in tweede instantie, op een moment dat 'dat de byna onerstellyke ravage al gedaen is'. ${ }^{54} \mathrm{Zij}$ vormt weliswaar een zichtbaar teken, maar geenszins de oorzaak van de ziekte.

Met deze opvattingen bevond Vilain XIIII zich in het gezelschap van zowat alle contemporaine medici die over deze

54 De Scheppere, Oordeel over de nature, 9. 
ziekte publiceerden. De Gentse artsen Somers en Vander Woestijne spreken van een 'subtil, doordringent en besmettende venyn' dat alle lichaamsvochten verderft en zo een 'brandende hitte, een rasse ontstekinge' veroorzaakt dat onstuitbaar uitmondt in 'Gangrene en Mortificatie'. De snelheid waarmee dit gebeurde hing in hun begrip af van traditionele galenische factoren als 'de jaeren, temperament, voedsel en stalling van de Beeste'. ${ }^{55}$ De eveneens Gentse medicus De Scheppere zocht de oorzaak in een 'contagieuse vergiftige stoffe $[. .$.$] van eenen putriden, al-$ kalinen, volatilen, subtilen, penetrerenden, corroderenden aert' die enkele dagen of zelfs weken nodig had om tot zichtbare uitwerkingen te komen. Hij beschrijft aan welke tekens de ziekte te herkennen valt tijdens een autopsie, maar opvallend is dat hij aangeeft dat deze eigenlijk zeer uiteenlopend zijn - longen, hersenen, keel, maag en darmen, lever en galblaas kunnen allen aangetast zijn of juist niet en zeker niet vastliggen. Ook hier blijkt dat de aantasting van organen volgt 'wanneer de gevitieerde, uytgebroude, infecterende stoffe, sig verschillig op d'inwendige deelen, ingewanden \&c. door de circulatie hebbende neergestelt'. De eigenlijke oorzaak is te zoeken in 'eene getroubleerde perspiratie, de circulatie des bloeds, en laeter d'humeuren t'eenemael vitierende, waer uyt volgen moeten obstructien, corruptien, inflammatien, geswellen, convulsien \&c. ende dat de maege ende de ingewanden moeten verliesen hun magt, als mede de zenuwen infaillibelyk buyten hunne actie worden gestelt'. ${ }^{56}$

55 J. Somers en J. Vander Woestijne, Ontwerp raekende de besmettelyke siekte van het hoorn-vee, desselfs toevallen en hulp-middels (Gent 1769) 9.

56 De Scheppere, Oordeel, 10.
Het ziekte- en lichaamsbeeld dat hier naar voren komt lijkt geïnspireerd door het denken van de bekende Nederlandse arts Herman Boerhaave, die het lichaam voorstelde als een hydraulisch systeem, waarbij gezondheid afhing van een vlotte en ongehinderde circulatie van lichaamsvochten. Ook is er een gelijkenis met de gedetailleerde reconstructie die Barbara Duden maakte van het lichaams- en ziektebeeld van de achttiende-eeuwse Duitse medicus dr. Johannes Stoch en zijn patiënten: binnen het lichaam circuleerden lichaamssappen, los van anatomische structuren. Het was de taak van de medicus om gezonde circulaties aan te moedigen, verkeerde bewegingen of blokkages te corrigeren en corrumperingen of excessen het lichaam uit te drijven. ${ }^{57}$ Zo kon een zwerende wonde een goed teken zijn - vervuiling of een teveel aan materie dat het lichaam verliet - en het verdwijnen ervan een reden tot bezorgdheid: de 'stroom' kon dan namelijk naar binnen getrokken zijn en daar belangrijke organen aantasten of verharden. ${ }^{58} \mathrm{Om}$ dit te verhelpen en deze 'stromen' op gang te brengen of terug in goede banen te leiden, schreef de medicus aderlatingen, etterdrachten of blaartrekkende producten voor. ${ }^{59}$ In wezen was dit een soort 'gefilterd' galenisme, dat zijn connecties met de Aristoteliaanse fysica grotendeels had verloren en verwerd tot een loodgieterij aan bewegende vochten.

57 Duden, The woman beneath the skin, 133. Dr. Stoch bevond zich in dit opzicht binnen de medische mainstream; zie bijvoorbeeld M. Lindemann, Health and healing in eighteenth-century Germany (Baltimore en London 1996) 262-271 en M. Fissell, Patients, power and the poor in eighteenth-century Bristol (Cambridge 1991) 16-37.

58 Duden, The woman beneath the skin, 132.

59 Ibidem, 134-135. 
Ook de hierboven geciteerde auteurs benadrukken de 'gegangreneerdheid' of 'putriditeit' van wat ze aantroffen bij autopsies van overleden dieren; ook koeimeesters, die eveneens dieren opensneden, kwamen overigens tot deze vaststelling. ${ }^{60}$ Zij zien hierin net als Stoch eerder gevolg dan oorzaak; het resultaat van verdorven lichaamsvochten die stagneerden en verrotten. ${ }^{61}$ De remedies die zij voorschreven lijken er dan ook op gericht om deze humoren terug te zuiveren en de gecorrumpeerde stoffen uit het lichaam te drijven: het ging daarbij om verschillende kruidenmengsels, aderlatingen, purgerende middelen en het steken van etterdrachten of 'vuurwortels'. De etterdracht was een touwtje dat bij runderen werd bevestigd in de keelkwab; door het touwtje te bewegen kon de wond opengehouden worden. Het doel hiervan was het doen vloeien van lichaamsvochten. De vuurwortel (Anacyclus pyrethrum, tegenwoordig bekend onder de naam bertram) diende hetzelfde doel: een stukje plant werd onder de huid aangebracht en zorgde daar voor een ontsteking. Het effect werd geïnterpreteerd als een positief 'afvloeien' van schadelijke stoffen. Ook veelvuldig roskammen werd uitdrukkelijk aangeraden, 'hier door worden de los-staende hairen weg-genomen, de vuyle korsten geruymt,

6o Zie bijvoorbeeld RAG, $S v V$, 11176 , brief van Jacobus Weemaes (Daknam, 29/10/1769) en RAG, $S v V$ 11175, brief van Pieter Van Loof (20/12/1769). In het midden van de achttiende eeuw was 'verrotting' een courante verklaring voor ziektes. Zie hiervoor M. Harrison, $M e$ dicine in an age of commerce \& empire. Britain and its tropical colonies 1660-1830 (Oxford 2010) 65-85.

61 Duden, The woman beneath the skin, 138. Een expert die zieke dieren aantrof te Houtem verklaarde niet voor niets ze te willen genezen 'principalyck met den cours van het bloedt liber te maken ende syne gewoonelycke circulatie te procureeren': RABR, $B B V, 597$, PV bij Pieter Deschadt (Houtem, 04/07/1770) de pori geopent, de transpiratie herstelt en vermeerdert, en aldus wordt aen de humoren den weg gebaent om langs desen eensdeels uyt het lichaem te gaen'. ${ }^{62}$

Eenzelfde redenering vinden we terug bij de West-Vlaamse koeimeester Jan Baptiste Hoornaert. Hij bemerkte dat vooral de longen van overleden dieren 'bedorven' waren. Hieruit leidde hij af dat de dieren die hij niet kon genezen, al te grote inwendige schade hadden opgelopen voordat uitwendige symptomen zichtbaar werden. Hij kon echter wel beterschap beloven 'voor de gonne wiens inwendighe infectatie, voor het inwendigh teekenen, soo verre niet gecomen en is' - met andere woorden, voor die dieren waarbij de ziekte zich nog niet had veropenbaard in enig orgaan, wat pas gebeurde op het moment dat 'de selve ten hoogsten in het bloet is gecomen'.

\section{Genezing in de praktijk}

De remedies die Somers en Vander Woestijne gebruikten in de abdij van Drongen volgden deze principes: de dieren werden adergelaten en er werd een etterdracht gestoken - het werd daarbij als een goed teken beschouwd wanneer de zo ontstane wonden begonnen te etteren. Daarna kregen de dieren elke dag een 'mixture minerale' en oximel (honingazijn) toegediend om de inwendige 'verroting' tegen te gaan en werden zij nauwgezet geobserveerd. Afhankelijk van hun toestand werd de dosering aangepast of kregen zij nogmaals een aderlating, 'naer proportie van hunne jaeren', of een etterdracht toegediend. Bij ernstige gevallen werd eveneens cinchona gegeven. Dieren die last kregen van con-

62 Somers en Vander Woestyne, Ontwerp, 15. 
stipatie werd een klisma toegediend; wanneer de muil was aangetast werd deze lichaamsholte uitgewassen met azijn of een aftreksel van kruiden. Aan zwakke dieren werd ten slotte bier of wijn gegeven ter versterking, of er werd karamel door hun gebruikelijke drank geroerd. ${ }^{63}$ De behandeling die Jan Baptiste Hoornaert een jaar later gebruikte, verschilt hier weinig van. Zijn standaardbehandeling bestond uit een 'zweetdrank' van theriac met bier of wijn om al het 'inwendigh fenyn uyt te jaeghen' en het wassen van de keel met azijn. Ook bedekte hij alle dieren met warme dekens en liet hij hen pap eten. Dieren die nog niet of net ziek waren, liet hij bloed af in de hals om hen te verlossen van 'quaedt bloedt'. Afhankelijk van het verloop van de ziekte en het 'temperament der beeste' beval hij meer of minder theriac toe te dienen. Bij ernstige gevallen liet hij ook wat bloed af onder de tong en diende hij een mengeling toe van boter, laurier- en komijnzaad 'omme alle inwendighen brandt uyt de levers te dryven', of hing hij een zak met warm haver aan hun hoofd 'om de slymen af te trecken'. ${ }^{64}$ Dieren met verstopping gaf hij een poeder van kolokwint, een laxerend middel, in melk of schaapzurkelsap.

De remedies van artsen en koeimeesters bestonden dus uit dezelfde middelen en hadden hetzelfde doel: de ziekte genezen door het behouden of herstellen van een gezond evenwicht van humoren en

63 RAG, $S v V$, 11175, rapporten van Somers en Vander Woestijne [december 1769].

64 RAG, $S v V$, 752, verslag van commissaris Mergaert (Beerst, 18/01/1771). Een kopie van dit verslag bevindt zich eveneens in RABR, Fonds Sanders, 820. Theriac was een geneesmiddel gemaakt van verschillende (en uiteenlopende) ingrediënten dat ook in de menselijke geneeskunde veelvuldig gebruikt werd, onder andere tegen de pest. een normale circulatie van lichaamsvloeistoffen. De behandeling was individueel in de zin dat de therapie werd aangepast aan de gesteldheid en de symptomen van het dier in kwestie.

Hoewel van Jan Baptiste Hoornaert het meest gedetailleerde verslag is bewaard gebleven, lijkt een dergelijke handelwijze vrijwel universeel geweest te zijn. Koeimeesters bedienden zich zowel van traditionele geneesmiddelen als theriac als van nieuwere, 'modieuze' middelen als antimonium. ${ }^{65}$ Ook met het steken van een etterdracht of vuurwortel zaten koeimeesters en medici op dezelfde golflengte. Vergelijk bijvoorbeeld de volgende behandelingen, de ene voorgeschreven door Somers en Vander Woestijne, de tweede uit een anoniem pamfletje uit 1744 waarin verschillende remedies van koeimeesters werden verzameld. Zo verschillend lijken ze niet:

Op den selven tydt is het ook geraedig vuur-wortels te steken in de agterste billen en steert, om alsoo aen de humoren meer als eenen weg te openen. ${ }^{66}$

Men moet de Beesten (om de quaetaerdige stoffe, die d'inwendige partyen nu geinfecteert heeft, naer't uytwendigh te brengen, ende alsoo te dissiperen ende cureren) eerst voor al van het Vuûr doen steken met Vuûrwortels of Nieswortel (Helleborus niger in 't latyn geseyt) in 't hangen van de twee Billen, item oock in 't hangen van de Borste, met de reflectie dat in elcken Bil moet ghesteken worden

65 Bijvoorbeeld RAG, $S v V$, 748, brief van J. Vispoel (Saffelare, 09/12/1769). Zie voor het groeiende gebruik van dergelijke metalen onder andere Harrison, Medicine in an age of commerce \& empire, 142-145. 66 Somers en Vander Woestyne, Ontwerp, 13. 
dry stucken van den voorschreven Vuûrwortel, ofte Nies-wortel, eenen vinger van elckanderen. ${ }^{67}$

De parallel tussen de opgegeven redenen: 'om aen de humoren meer als eenen weg te openen' en 'om de quaetaerdige stoffe, die d'inwendige partyen nu geinfecteert heeft, naer't uytwendigh te brengen' is duidelijk. In beide gevallen moesten gecorrumpeerde lichaamsvloeistoffen naar buiten worden geleid, weg van de belangrijkste organen. Het steken van een 'vuurwortel' was dus geen cosmetische ingreep: het etteren van deze wonde werd geïnterpreteerd als het wegvloeien van de schadelijk geworden humoren, die letterlijk naar de oppervlakte getrokken werden. Deze remedie behoorde tot het standaardrepertorium van koeimeesters en veehouders en wordt meermaals gesignaleerd of aangeraden door diverse brievenschrijvers. ${ }^{68}$ In een brief van de abt van de Antwerpse Sint-Michielsabij wordt het steken van een etterdracht bijvoorbeeld vermeld als een goede behandeling aangeraden door 'eenen persoon van kennisse die eenen grooten Weyder van vee is, ende de Sieckte en Sterfte onder het

67 Rijksarchief Anderlecht [RAA], Staten van Brabant [SvB], supplement 743, drukwerk getiteld 'Tegens soo eene haestige ende scherpe sieckte...'.

68 Buiten de gegeven voorbeelden, zie ook bijvoorbeeld RAG, $S v V, 11176$, brief van paarden- en koeimeester Jacobus Weemaes (Daknam, 29/10/1769); RAG, $S v V, 1_{1176}$, bijvoegsel bij brief van Vanden Cruyce getiteld 'Remedie van Guillielmus Pauwels smit van Calmthout'. (Hoogstraten, 19/11/1769); Rijksarchief Beveren, Oud gemeentearchief Essen, document met hoofding 'Remedie voor de hooren beesten uyt welckers muyl zeever loopt de oogen root en treenen en geen melk gevende [...] worden gegeven by experientie door den Heer G: van der Schilder vicarius vallis libor anno 1748'; RABR, $B B V$, 598, document met hoofding 'Geneesmiddel ende maniere omme den selven te gebruycken'. selve op de voorige tyden heeft bygewoont'. Hier is de reden 'dat de sieckte begint van het hooft, ende by middel van het voorschreve, de obstructie in het hooft can lostgemaeckt worden, ende de beeste alsoo gesalveert worden'. ${ }^{69}$

Somers en Vander Woestijne adviseerden overigens deze etterdrachten ook preventief te steken. ${ }^{70}$ Dat dit ook gebeurde blijkt uit een rapport uit Meerhout. Een landbouwer liet optekenen dat hij de gewoonte had om jaarlijks zijn dieren te laten aderlaten of om een 'vuurstok' te doen steken, aangezien zij op stal stonden en het daar warm was. ${ }^{71}$ Dat dit blijkbaar jaarlijks gebeurde, versterkt de indruk dat hier niet louter het advies van Somers en Vander Woestijne werd toegepast. Het ging hier om een remedie die door alle lagen van de bevolking werd gebruikt, om dezelfde reden. ${ }^{72}$

69 RAA, SvB, kartons 468/5, brief van abt Antonius (Antwerpen, 21/12/1769).

70 Somers en Vander Woestijne, Ontwerp, 18.

71 RAA, SvB, kartons 469, formulier omtrent Christiaan Peermans (Meerhout, o1/08/1776). De gegeven motivatie, de warmte in de stallen, doet denken aan de toen gebruikelijke gewoonte reizigers naar tropische gebieden preventief te aderlaten: Harrison, $\mathrm{Me}$ dicine in an age of commerce \& empire, 128.

72 Ronald Rommes komt tot dezelfde conclusie voor Utrecht, waar deze remedie blijkbaar bekend stond als het 'Spaans vuurkruid' en op dezelfde manier gebruikt werd: Rommes, 'Geen vrolyck geloei', 126. Van een religieus-geïnspireerd fatalisme, waar deze auteur eveneens melding van maakt, lijkt er in de Oostenrijkse Nederlanden overigens geen sprake te zijn geweest. Maar zie F. Egmond, 'De aansprakelijkheid van God. "Gewone" Nederlanders en bijzondere natuurverschijnselen in de zestiende eeuw', in: Gijswijt-Hofstra en Egmond ed., Of bidden helpt?, 11-27 voor een belangrijke nuancering van het belang van religieuze verklaringswijzen tout court. 


\section{'Met handen ende vingers'}

Interessant is dat ook de legitimering van autoriteit en de verklaring voor het falen van remedies bij medici en experts op eenzelfde manier verliep. Waarom moest er naar hen geluisterd worden? Omdat hij de uitbraak van 1744 had meegemaakt en daarbij veel ervaring had opgedaan, voerde Hoornaert aan. Ook de overheden vonden ervaring een van de belangrijkste voorwaarden waaraan een koeimeester moest voldoen. Toen in februari $1772 \mathrm{de}$ parochies van de kasselrij Kortrijk gevraagd werd een expert voor te dragen, was ouderdom en ervaring met vorige uitbraken duidelijk een van de belangrijkste kwalificaties, samen met een goede reputatie. $^{73}$

Toch moet hieruit niet geconcludeerd worden dat koeimeesters zich louter beriepen op hun ervaring: volgens Hoornaert was deze juist relevant omdat hij hierdoor in staat was de soms subtiele en veranderlijke tekenen van de 'besmettelijke ziekte' te onderscheiden van die van andere mogelijke aandoeningen. Zo kon hij de juiste middelen voorschrijven en afstemmen op het temperament van het getroffen dier. Indien de foute middelen werden gebruikt, zou dit er immers voor zorgen dat het dier 'noch meer souden ontsteken ende het inwendigh venyn vermeerderen'. ${ }^{74}$ Ervaring op zich was dus niet genoeg: deze hielp om de juiste diagnose te kunnen maken, waarna de behandeling kon worden afgestemd op de oorzaak van de ziekte en de gesteltenis van het individuele rund. De koeimeesters waren dus niet louter 'empirici' die in het

73 RABR, $B B V, 604$.

$74 \mathrm{RAG}, S v V, 75^{2}$, verslag van commissaris Mergaert (Beerst, 18/01/1771).

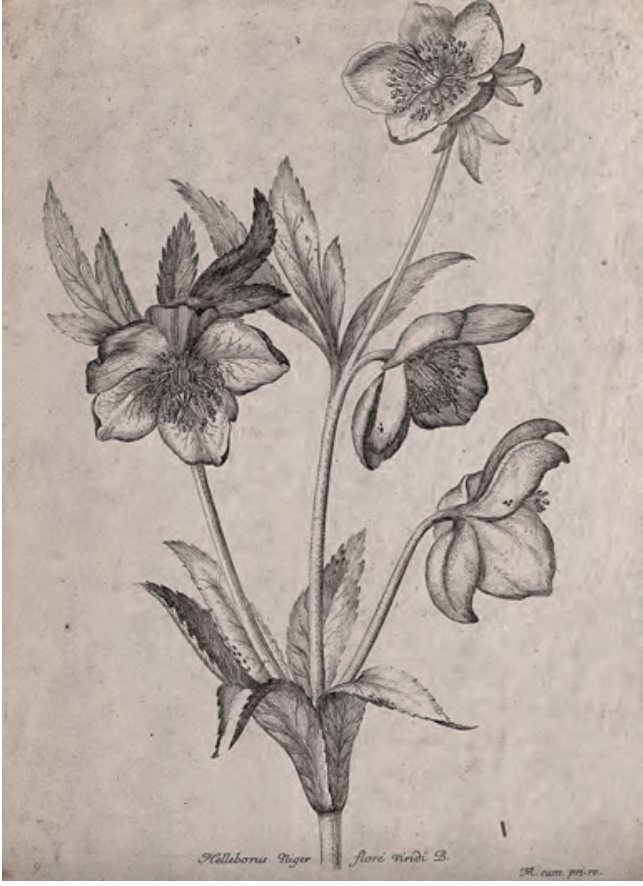

Ets van een kerstroos (helleborus niger), gebruikt om dieren 'van het vuur te steken'

Wellcome Library, London

wilde weg middeltjes gebruikten zonder daar een onderbouwde reden voor te hebben, in de hoop eerder behaald succes te herhalen. ${ }^{75}$ De medicus De Scheppere verdedigde in dezelfde termen de superioriteit van zijn kennis: ook hij had de uitbraak van 1744 meegemaakt en ook hij wist dat het gevaarlijk was 'van in't wilde, op eenige equivoque teekenen, ofte op sistematique suppositien, remedien voor-teschryven; 't Empyrismus, 't gone meest de violente ofte drastique remedien werkstellig maekt, aen de konste verfoeyelyk zynde'. ${ }^{76}$

75 Wat dit betreft is het wel interessant dat van sommige koeimeesters expliciet gezegd werd dat hun vaders en grootvaders zich ook bezighielden met het 'cureren' van dieren. Bvb. RABR, $B B V$, 604, brief van het lokaal bestuur van Wingene (05/02/1772). Theoretische kennis kon uiteraard ook langs deze weg overgedragen worden. 76 De Scheppere, Oordeel, 5 . 
Ook wanneer het fout liep en er toch runderen stierven zijn de parallellen opvallend. Hoornaert had 'met handen ende vingers' aan de eigenaars getoond hoe ze de remedies moesten klaarmaken en toedienen, maar natuurlijk was dit niet altijd op de goede manier gebeurd. Hij twijfelde of zijn instructies juist werden uitgevoerd en hij was er zeker van dat dit sowieso te laat was gebeurd. In twee gevallen waren er zelfs dieren doodgegaan omdat de eigenaars een foute, te drastische remedie hadden gebruikt: één dier werd adergelaten in het oor, 'welcke het bloedt soodanigh is afgheloopen, daer naer haer doodt om seggens gheen bloedt meer over haer en is bevonden'. Bij een ander dier werd zulk een krachtig laxeermiddel toegediend dat het 'alsnu buyten alle hope schynt'. ${ }^{77}$ Ook de kuur van Somers en Vander Woestijne, of toch althans in die stal waar ze er niet te laat bij waren gehaald, mislukte uiteindelijk omdat een knecht op eigen houtje besloot de dieren een neusspoeling van wijnazijn toe te dienen. Een veel te zwaar middel, oordeelden de dokters. Na dit voorval verslechterde de toestand van de hen toevertrouwde dieren zienderogen, en uiteindelijk stierven deze. $^{78}$

Zowel experts als medici meenden dus dat zij door hun ervaring en kennis de ware aard van de ziekte verstonden, en dat zij daardoor op de gepaste wijze konden ingrijpen. Elk ziek individu was namelijk anders, en het terug in balans brengen van de lichamen van zieke dieren was een delicate opdracht: een fout geneesmiddel kon de ziekte juist bevorderen of

77 RAG, $S v V$, 752, verslag van commissaris Mergaert (Beerst, 18/01/1771).

78 RAG, $S v V$, 11175, brief Somers en Vander Woestijne (19/12/1769). het evenwicht finaal verstoren. Waar zij genezing verwachtten en deze toch niet kwam, werd dit onder meer geweten aan boeren en knechten die instructies niet goed opvolgden of op eigen houtje te drastische, gevaarlijke remedies betrachtten.

De scherpe kritiek die medici soms leverden op experts, zoals Somers en Vander Woestijne die schrijven over 'de onwetendheid der Heelmeesters' en vinden dat 'de Vlaemsche Meesters' op de foute manier aderlaten, moet mijn inziens dan ook veeleer geïnterpreteerd worden als een sociologisch conflict, een manier om de eigen kennis boven die van de ander te stellen, dan als bewijs van scherp uiteenlopende kennissystemen. ${ }^{79}$

Verschillende historici maakten al het punt dat artsen hun expertise vóór de opkomst van de moderne geneeskunde op een onderscheidende manier moesten aanprijzen en zichzelf volgens andere maatstaven beoordeelden: 'Success was distinguished by patients, fame as a teacher and a fat income'. ${ }^{80}$ Het lot van een medicus was dus afhankelijk van de contacten die hij legde en de mate waarin hij zijn patiënten tevreden stelde. ${ }^{81}$ In de Oostenrijkse Nederlanden waren geneesheren, chirurgijns en apothekers verenigd in Collegia Medica, die in de loop van de zeventiende en achttiende eeuw in verschillende steden werden opgericht. Deze Collegia werden opgericht bovenop

79 Somers en Vander Woestyne, Ontwerp, 6 en 10. François Vallat komt tot een gelijkaardige conclusie voor Frankrijk: Vallat, Les boufs malades, 242.

80 R. French, Medicine before science. The business of medicine from the middle ages to the Enlightenment (Cambridge 2003) 257 .

81 Zie hierover N.D. Jewson, 'Medical knowledge and the patronage system in 18th century England', Sociology 8 (1974) 369-285 en N.D. Jewson, "The disappearance of the sick-man from medical cosmology, 17701870', Sociology 10 (1976) 225-244. 
al bestaande ambachten zoals die van de barbierchirurgijns en kwamen in feite neer op een putsch van academisch geschoolde dokters tegenover apothekers en chirurgijns. ${ }^{82}$

Niet alleen probeerden medici macht te verwerven ten opzichte van deze twee verwante beroepen, maar tegelijkertijd werd ook getracht de medische markt zoveel mogelijk af te schermen van buitenstaanders. Opvallend is dat ook hier vaak verwezen werd naar een bijzondere competentie als rechtvaardiging voor collectieve rechten en verworvenheden, maar dat het bijna als gegeven werd beschouwd dat een ambachtslid ook competent was. ${ }^{83}$ Op het platteland was de invloed van de Collegia Medica echter zeer beperkt: om hun bekwaamheid en superioriteit ten opzichte van de koeimeesters te vestigen en daarmee dus hun eigen diensten en geneesmiddelen aan te prijzen moesten medici hun toevlucht nemen tot gedrukte pamfletten en retoriek. ${ }^{84}$ Het is wellicht niet zonder betekenis dat het boekje van De Scheppere eindigt met de melding dat een bepaalde remedie is te bekomen tot Gendt, ten huyse van Sr. Pieter François Hellebaut, woonende in de Velt-straete'. ${ }^{85}$ Ook de veepestbestrij-

82 B. De Munck, 'Medische praktijken. Conflicten rond competentie in de Antwerpse medische sector, 17 de en 18de eeuw', Tijdschrift voor sociale geschiedenis 27.4 (2001) 464 .

83 Ibidem, 462 .

84 R. Schepers, De opkomst van het medisch beroep in België. De evolutie van de wetgeving en de beroepsorganisatie in de 19de eeuw (Amsterdam 1989) 18; P. Lenders, Overheid en geneeskunde in Habsburgse Nederlanden en het Prinsbisdom Luik (Kortijk 2001) 40.

85 De Scheppere, Oordeel, (laatste blad, zonder nummer: 'By-Voeghsel'. Dit bijvoegsel ontbreekt in de versie die bijvoorbeeld ingescand te vinden is op Google Books, maar is aanwezig in het exemplaar bewaard te Anderlecht: RAA, Staten van Brabant, kartons 468/11. ding zelf kon best lucratief zijn: Somers en Vander Woestijne kregen voor hun experimenten in Drongen een som van 500 gulden courant $\mathrm{t}^{86}$; koeimeesters kregen een vergoeding van zo'n 12 stuivers per examinatie die zij deden. ${ }^{87}$ Dit vooruitzicht op patronage verklaart wellicht ook waarom zowel Somers en Vander Woestijne als De Scheppere zich in hun boekjes, hoewel zij daarin verschillende mogelijke remediën beschrijven, eveneens scharen achter het overheidsingrijpen en zich positief uitlaten over de slachtpolitiek: een al te kritische houding werd niet bijster geapprecieerd. ${ }^{88}$

\section{Conclusie}

In zijn verdediging van de slachtpolitiek schept voorschepen Vilain XIIII een bijna apocalyptisch beeld: het 'besmettelijk venijn' dat de runderen aantastte vermeerderde zich gestaag in hun lichamen, verspreidde zich door de lucht en klampte zich vast aan alle losse en vaste objecten in de omgeving:

Dat de athmosphére, ofte omswevende logt, den geur, ofte reuk van de besmette beesten, dat de menschen en andere gedierten door hun hair ofte wolle, ja selfs dat de doode ende onroerelyke saeken, soo als is het hout, stroy, spoele, aele,

86 Wat neerkomt op ongeveer 41 ponden groten Vlaams per persoon. Ter vergelijking: de abt van Drongen kreeg de volledige waarde van zijn dieren vergoed, een som van 10 ponden groten Vlaams per koe. 87 Bvb. RAG, $S v V$, 11181C. Staat van onkosten (Kruibeke, og/05/1772).

88 Zie bijvoorbeeld RAG, $S v V, 11176$, brief van Vanden Cruyce (Antwerpen, 29/01/1770) waarin wordt beschreven hoe de publicatie van een kritischer manuscript werd verhinderd. 
wolle-laeken besmettelyk zyn van het selve venyn, soo dat dese by geval naederende aen eenige levende Hoornbeesten, de selve 't zy door den reuk, ofte andere onsienbaere wyze besmetten. ${ }^{89}$

De slachtpolitiek was voor hem de enige oplossing aangezien 'eene beeste die besmet is, hoe langer sy leeft, hoe meerder haar venyn wort, en hoe kragtiger sy het selve aen al dat ontrent haer is mededeelt'. ${ }^{90}$ Dat is de reden dat alle gezonde dieren die zelfs maar in de nabijheid van besmette dieren zouden hebben gestaan terstond geslacht moesten worden. Hopen op genezing deed meer kwaad dan goed: niet omdat de koeimeesters incompetent zouden zijn, maar vooral omdat dit het venijn meer tijd zou geven om in kracht toe te nemen. De idee van een uiterst besmettelijk venijn dat zich bovendien kon verspreiden lang voordat de ziekte merkbaar werd, was al snel bij Vilain XIIII aanwezig, getuige het verbod op veemarkten en de motivering hiervan. Deze bekommernis bleef hij ook in latere jaren houden: toen de ziekte zich in 1771 had verspreid over het Brugse Vrije, verdedigde hij de beslissing om de slachtpolitiek hier tijdelijk niet meer uit te voeren:

La multitudes de betes infectées ainsi que l'effusion de leur sang peut et doit rendre le sol ainsi que l'atmosphere d'une paroisse tellement infecté que sans aucune autre communication, la plupart du betail est exposé à la maladie et que la tuerie du bétail infecté, ainsi que celui qui a eu communication ne devient pas

89 Vilain XIIII, Verhael ende reflexien, 5. 90 Ibidem, 23. seulement inutile, mais même pernicieuse $^{91}$

Het slachten van dieren zou de ziekte hier niet meer tegenhouden, omdat de lucht en de bodem al vergeven waren van het besmettelijk venijn. Zelfs de voornaamste pleitbezorger van de slachtpolitiek in Vlaanderen was er dus van overtuigd dat deze haar grenzen had en vanaf een zekere ziektegraad niet meer werkzaam zou zijn. Het vermijden van dit soort situaties was en bleef voor de centrale overheid en voor de gedeputeerden van de Staten van Vlaanderen een belangrijk streven, en het was dit gevaar van escalatie dat het genezen van runderen niet kon vermijden. De proefnemingen bleven daarom beperkt tot periodes waarin de ziekte niet meer onder controle te brengen leek: pogingen dieren te genezen werden enkel aanvaardbaar geacht waar het venijn zich toch al hopeloos verspreid had.

De experimenten die werden ingericht te Drongen en in het Brugse Vrije waren er vanuit de overheid bovendien op gericht een snel, gemakkelijk toe te dienen en effectief geneesmiddel te vinden. Zoals we echter hebben gezien, legden noch artsen, noch koeimeesters zich hier op toe. Hun proefnemingen bestonden niet uit het toedienen van één enkel middel, maar

91 RAG, $S v V$, 1118oB, handschrift van Vilain XIIII met de hoofding 'Observations sur les moyens la plus propres à employer dans l'etat present des choses relativement à la maladie contagieuse qui regne parsui les betes à cornes' (Gent, 05/12/1771) 'De grote hoeveelheid geïnfecteerde dieren, evenals het vergieten van hun bloed, kan en moet de grond en de atmosfeer van een parochie zo infecteren dat zelfs zonder bijkomende communicatie het merendeel der dieren blootgesteld wordt aan de ziekte en dat de slacht van geïnfecteerde dieren en de dieren waarmee zij contact hebben gehad niet enkel nutteloos, maar zelfs gevaarlijk wordt.' 
uit een assemblage van technieken en middelen die erop gericht was de humoren van de zieke dieren te zuiveren en terug in balans te brengen: dit was per definitie een langdurig, individueel proces dat uiterst afhankelijk was van de vaardigheid en kunde van de behandelende expert. De verklaring voor het feit dat deze experimenten geen vervolg kregen, moet dus niet worden gezocht in anachronismen als de afwezigheid van werkelijk doeltreffende geneesmiddelen. Men had wel degelijk redenen kunnen vinden om over te gaan tot verdere proefnemingen, zoals de proefnemingen rond de besmettelijkheid van huiden en andere objecten wel werden voortgezet: enkele van de geteste remedies waren duidelijk effectiever dan andere en boden het vooruitzicht op nog betere behandelingen indien storende factoren - recalcitrante stalknechten, slome boeren - zouden worden weggenomen. ${ }^{92}$ Telkens weer bleek genezing echter een langdurig en moeizaam proces dat het risico op verdere besmetting zou vergroten: zeker omdat men al in de eerste maanden van de uitbraak tot de conclusie was gekomen dat de ziekte zich op allerlei indirecte manieren kon verspreiden en dat dit moeilijk te verhinderen viel. De slachtpolitiek bleef over als

92 Wetenschapshistorici benadrukken dat wat telt als een 'geslaagd' experiment ook een kwestie is van cultuur en sociale constructie. Zie bijvoorbeeld H.M. Collins, "The seven sexes. A study in the sociology of a phenomenon, or the replication of experiments in particle physics', Sociology 9 (1975). Wat dit betreft lijkt het me absoluut relevant dat van een geïnstitutionaliseerde (diergeneeskundige) wetenschap nog geen sprake was en dat de proefnemingen gebeurden op momenten en condities bepaald door de provinciale overheid. De experts die deze proefnemingen organiseerden, hadden niet het vermogen hun eigen percepties door te drukken, te bevestigen, of zelfs maar publiek te maken. enige aanvaardbare alternatief, en omdat periodes van onbedwingbaarheid en periodes waarin de ziekte leek te zijn verdwenen elkaar snel opvolgden, leken de ruimingen ook effectief. ${ }^{93}$

Aan de andere kant verloor de expertise van de koeimeesters nooit haar geloofwaardigheid: ze paste perfect binnen de mainstream van het dominante medische discours. Het werd algemeen aanvaard, ook door de bestuurlijke elite, dat de ziekte verschilde van individu tot individu en in dit geval van stal tot stal, en dat daarom het vinden van een simpele remedie jammerlijk onmogelijk was. Ook academisch geschoolde artsen konden geen betere resultaten voorleggen. De negatieve retoriek waarmee de proefnemingen werden omschreven door Vilain XIIII en de centrale overheid lijkt er dan ook vooral op gericht geweest te zijn om andere leden van de bestuurlijke elite - zoals de kasselrijbesturen - over te halen om de slachtpolitiek te steunen en nauwgezet toe te passen - net zoals de negatieve retoriek ten opzichte van koeimeesters in het boekje van Somers en Vander Woestijne er op gericht was om zich te profileren ten opzichte van een concurrerende categorie experts. Tijdens deze uitbraak van veepest zouden artsen echter nooit de plaats innemen van de koeimeesters: wellicht was het wegens het belang van een snelle uitvoering van de edicten ook logistiek gemakkelijker om te vertrouwen op een categorie experts die in nagenoeg elke plattelandsparochie te vinden was. De koeimeester bleef in de strijd tegen de veepest voorlopig de sleutelfiguur.

93 Het blijft een open vraag in hoeverre de slachtpolitiek ook werkelijk effectief was; in ieder geval bevorderde het verloop van de epizoötie deze perceptie. 


\section{Over de auteur}

Filip Van Roosbroeck is houder van een aspirantenmandaat van het FWO-Vlaanderen en is verbonden aan de Universiteit Antwerpen. E-mail: filip.vanroosbroeck @uantwerpen.be 
